\title{
BMJ Open Development of an interprofessional collaboration competency scale for children with medical complexity
}

\author{
Keiko Shimmura, ${ }^{1}$ Etsuko Tadaka ${ }^{2}$
}

To cite: Shimmura K, Tadaka E. Development of an interprofessional collaboration competency scale for children with medical complexity. BMJ Open 2018;8:e019415. doi:10.1136/ bmjopen-2017-019415

- Prepublication history for this paper is available online. To view these files, please visit the journal online (http://dx.doi. org/10.1136/bmjopen-2017019415).

Received 1 September 2017 Revised 13 April 2018 Accepted 20 April 2018
Check for updates

${ }^{1}$ Asukayama Visiting Nursing Station, Japan Visiting Nursing Foundation, Tokyo, Japan ${ }^{2}$ Department of Community Health Nursing, Graduate School of Medicine, Yokohama City University, Yokohama, Japan

Correspondence to Dr Keiko Shimmura; kei.0.0.s.otegami@gmail.com

\section{ABSTRACT}

Objective To develop and validate an interprofessional collaboration competency scale for children with medical complexity (ICC-CMC). These children have the most complex healthcare needs, complicated chronic conditions, severe functional limitations and often need a considerable amount of healthcare resources.

Design Cross-sectional study.

Setting The self-administered ICC-CMC questionnaire was developed based on a literature review and 12 expert interviews.

Participants Participants were 2347 interprofessionals from the health, medical, welfare and education fields in seven prefectures in Japan.

Main outcome measure(s) We used Cronbach's alpha values to assess the internal consistency of the scale. Construct validity was confirmed with confirmatory factor analysis, and an existing scale was administered to assess criterion-related validity.

Results In total, 378 professionals provided valid responses. Exploratory and confirmatory factor analyses identified 12 items on three factors: 'sharing needs assessment skills', 'resource development skills' and 'creative networking skills'. The final model showed good fit on four indices (eg, goodness of fit index: 0.925). The Cronbach's alpha for the entire scale was 0.93 and was above 0.80 for each factor. The correlation coefficient between the existing scale and the ICC-CMC was 0.72 $(p<0.001)$.

Conclusions The ICC-CMC demonstrated acceptable internal consistency and validity. The scale has potential use in advancing professionals' individual practice and team performance in interprofessional collaboration. In addition, the ICC-CMC has the potential of improving satisfaction and outcomes for children with medical complexity and their families.

\section{INTRODUCTION}

The Maternal and Child Health Bureau defines children with special healthcare needs as those with increased risk of a chronic physical, developmental, behavioural or emotional condition, who require healthcare and related services beyond that required by children in general. ${ }^{1}$ Children with medical complexity (CMC) make a significant portion of this group. As well as complex healthcare needs,

\section{Strengths and limitations of this study}

This study develops and validates a novel interprofessional collaboration competency scale for children with medical complexity (the ICC-CMC).

- The data have clarified the confirmative concept of the ICC-CMC consisting of 'sharing needs assessment', 'resource development' and 'creative networking'.

- The participants of this study include 2347 representative interprofessionals from the health, medical, welfare and education fields for CMC in Japan.

- The study design was cross-sectional. Future research should seek to evaluate a predictive validity and to identify factors related to the ICC-CMC.

complicated chronic conditions and severe functional limitations, CMC often require a considerable amount of medications, services and family support to maintain a basic quality of life. ${ }^{2}$ In Canada, CMC comprise $<1 \%$ of the paediatric population but account for nearly one-third of paediatric healthcare spending and more than one-quarter of paediatric hospital readmissions. ${ }^{3}$ In Japan, the number of $\mathrm{CMC}$ is increasing because of the increased survival rate of infants born prematurely and improved intensive medical treatments and nursing care for acute illnesses. ${ }^{4}$ In 2011, around 111000 children in Japan had child chronic diseases, representing a 2.8\% increase in past 6 years. ${ }^{5}$ Moreover, in 2010, $68.4 \%$ of these children had severe physical disability, representing a $12 \%$ increase over 15 years. ${ }^{6}$ Therefore, CMC are a growing sector of the paediatric population and are becoming a key population of interest in health reform efforts in developed countries.

Regardless of underlying diagnoses, CMC share special healthcare needs, including: (1) intensive hospital-based and/or community-based services; (2) reliance on technology, polypharmacy and/or home care or congregate care to maintain a basic quality of life; (3) risk of frequent and prolonged hospitalisation, leading to high resource use; and (4) 
an elevated need for care coordination. ${ }^{7}$ In Japan, almost $70 \%$ of seriously ill children with a severe condition who have such needs are living in the community without supportive care. ${ }^{8}$ In addition, caregivers of technology-dependent children experience more anxiety, anger, sorrow, social isolation and depression compared with parents of able-bodied children. ${ }^{9}$ Despite improvements in medical technology, the widespread home use of medical equipment, and governmental facilitation of positive discharge from hospital, community-based support systems often cannot respond to demand. Problems include human resources shortfalls, absence of a care coordinator, difficulty of longitudinal and continuous involvement and an undeveloped legal system that does not connect health, medical, social and education professionals. ${ }^{10}$ Therefore, the coordination needs of children and parents remain unmet in many cases. ${ }^{11}$ Interprofessional collaboration across a range of health, medical, welfare and education specialties is central in responding to the special healthcare needs of CMC. Previous studies showed comprehensive care provided by multiple professionals reduced serious illness, emergency department visits, total hospital and clinic costs and improved children's social and emotional quality of life. ${ }^{12-14}$ This highlights that interprofessional collaboration is one of the important factors to enhance the well-being of CMC.

To promote and improve interprofessional collaboration for $\mathrm{CMC}$, it is necessary to clarify interprofessional collaboration competency and assess the practices considered for the next step in collaboration. Interprofessional collaboration competency is measurable and refers to the underlying characteristics, including knowledge, skill and attitude, required of professionals ${ }^{15}$ in the process wherein professionals from different areas have the same objectives and work together. Various interprofessional collaboration scales are available to generate one's or team's self-reflection. Kenaszchuk $e t a l^{16}$ developed a multigroup measurement scale for interprofessional collaboration, but this scale is created from on a nursing-centred questionnaire, and physicians and nurses are item targets, not for other health professionals. Heinemann et al ${ }^{17}$ developed a measure of attitudes towards healthcare teams among team members and/or trainees and their supervisors, but this was designed for clinically based teamtraining programmes for medical and health professions students and residents, instead of community-based interprofessional teams. Sakai et $a l^{18}$ developed an exhaustive measurement of interprofessional collaborative competency; however, medical professions in hospital setting are item target, not for interprofessional consisting of home care professionals. Therefore, existing measurements are developed for clinical-based, medical professional group, typically physicians and nurses, cross-sectional and specific interprofessional collaboration competency not suitable for CMC. Interprofessional collaboration for CMC requires community-based, multiple interprofessional collaborative relationships, longitudinal and comprehensive competencies.
We developed and validated a new interprofessional collaboration competency scale for CMC (ICC-CMC). This study clarified the reality of interprofessional collaboration competency, and if used as a practical assessment in developing community care systems, the ICC-CMC may contribute to improvement of collaboration and quality of life for children and their families.

We defined 'interprofessional collaboration' as a process wherein professionals from different areas (health, medical care, welfare, education and government) have the same objectives and work together to ensure the quality of life for CMC. ${ }^{19-21}$ 'Competency' (defined as the underlying characteristics including knowledge, skill and attitude required of professionals) reflects factors that can be changed and developed. ${ }^{15}$

\section{METHODS}

\section{Phase 1: developing the instrument}

First, we developed a pool of items verbatim based on a literature review. Studies on concepts of collaboration and collaboration scales ${ }^{22-29}$ and collaboration in children's home care were searched in PubMed and Ichushi-Web, using collaboration, cooperation, continuity of care, integration, linkage, interprofessional, multiprofessional, team, home care, community care, measurement and scale for search terms; therefore, 37 articles were identified. Item inclusion criteria were based on the process of interprofessional collaboration for CMC (rather than the structure), adaptation of the given item for multiple professionals (rather than for particular professionals) and practical usefulness. Throughout the process, 34 items were developed for originally scale.

Next, the item pool was reviewed by 10 professionals and 4 researchers to assess content validity, face validity and practical usefulness via interviews ${ }^{29}$ or questionnaires. Participating professionals included paediatric physicians, a paediatric nurse and a discharge nurse, home visiting nurses, a public health nurse, a social worker and teachers with over 5 years of experience in job performance and collaboration with interprofessionals for more than five CMC cases. To achieve a variety of perspectives on measurement, we considered the balance of professionals and recruited professionals from different disciplines or institutions. The researchers were from the Department of Community Health Nursing or Home Care Nursing who had proven records of measurement development. We excluded items assessed as 'not important' by more than one expert. Moreover, we expressed the wording of items clearly based on the expert opinion (eg, profession$\mathrm{al} \rightarrow$ other professional), for example, expressing the topic clearly, using 'other professional' rather than 'multiprofessional' to clarify the focus, ensuring item relevance for both child and family and selecting wording that better assessed collaboration in double-barrelled questions. The initial ICC-CMC was refined to 30 items on four preliminary domains: sharing information, understanding 
function, coordinating support objectives and securing networks.

\section{Phase 2: validating the instrument Participants}

This survey involved 2347 professionals from 1459 institutions in seven prefectures in Japan. Inclusion criteria were: (1) experience of interprofessional collaboration for CMC in the past year and (2) one of the defined professional groups (representative person) from each institution or section. Selected professional groups were: paediatric physician (paediatric department in a hospital/ child welfare institution), paediatric nurse (paediatric department in a hospital, discharge centre in a hospital or child welfare institution), home visiting nurse (home visiting care station), public health nurse (community health centre), social worker (community health centre), school nurse (special school) and nursery teacher (child welfare institution).

Data were collected in seven prefectures that house Japan's major cities (Hokkaido, Tokyo, Kanagawa, Aichi, Osaka, Hyogo and Fukuoka). These prefectures cover nearly half of Japan's population and include more service-offering institutions than other prefectures. Institutions were selected from publicly available information lists by either complete or systematic random sampling. We mailed informed consent letters and the ICC-CMC questionnaire to administrators and eligible participants at each institution. Participants were invited to complete the self-administered, anonymous questionnaire voluntarily. Of the potential participants, 411 (17.9\%) responded, and $378(92.0 \%)$ questionnaires with valid responses (excluding no answering of demographic characteristics) were available for analysis.

\section{Measures}

We collected participants' demographic characteristics including gender, age, main qualification, years of work experience, affiliated institution and years of experience in CMC support. The importance of each ICC-CMC item was investigated using a four-point Likert-type scale. Participants rated each item as: 'Not important: 0', 'Not important to a certain extent: 1', 'Important to a certain extent: 2' or 'Important: 3'. An additional response option was 'I don't know'.

Participants were asked to recall one CMC case example in which they experienced interprofessional collaboration and self-assess collaboration practice based on that example. Each item was assessed on a four-point Likerttype scale: 'Disagree: 0 ', 'Disagree to a certain extent: 1', 'Agree to a certain extent: 2' and 'Agree: 3'. We also asked participants to record CMC demographic characteristics including gender, age, basic disease, medical care and professionals involved in the collaboration.

To assess the construct validity of the ICC-CMC, participants also completed Fukui's scale (self-assessed), which is a measure of the face-to-face cooperation level among home healthcare providers ${ }^{26}$ on the hypothesis that ICC-CMC and Fukui's scale are relevant. This scale consists of 21 items (eg, I understand what other professionals can do) on seven subscales, with responses on a five-point Likert-type scale (from disagree $=1$ to agree $=5$ ). The total score ranges from 21 to 105, with higher scores indicating greater face-to-face cooperation among home healthcare providers. This scale had a Cronbach's alpha of 0.94 and has been shown to be valid and correlated with the level of interprofessional collaboration in the community and participation in interprofessional collaboration meetings. We used this scale because the content was relevant to the ICC-CMC in terms of care recipient, involvement of professionals from various fields and development in community settings.

\section{Statistical analysis}

All analyses were conducted with IBM SPSS Statistics 20.0 and Amos 20.0 (Chicago, Illinois, USA). The total sample $(n=378)$ was randomly divided into two split samples for cross-validation: group $1 \quad(\mathrm{n}=162)$ for performing item and exploratory factor analyses and group $2(\mathrm{n}=216)$ for performing confirmatory factor analysis. Item and exploratory factor analyses were conducted to investigate the reliability and convergent validity of the ICC-CMC. The criteria for item analysis included pass efficiency (average score $<1.0$ point), rates of response difficulty (unknown and non-respondents: $\geq 5 \%$ ), distribution (ratings of 'Important to a certain extent'/'Important' by $<90 \%$ of the sample), good-poor analysis (no significant difference between the highest scoring and lowest scoring groups) and item-total analysis (correlation coefficient: $<0.3$ ).

After the item analyses, we examined the remaining items with exploratory factor analysis (principal factor analysis) with promax rotation as a first step. The optimal number of factors was determined using eigenvalues and a scree plot. Item loadings needed to exceed 0.40. Factor reliability was determined using Cronbach's alpha $\geq 0.70,{ }^{30}$ and construct validity was verified with confirmatory factor analysis. Model fit was examined with the goodness of fit index (GFI), adjusted GFI (AGFI), comparative fit index (CFI) and root mean square error of approximation (RMSEA). ${ }^{31}$ Construct validity was also examined by the correlation between the ICC-CMC and Fukui's scale.

\section{Patient and public involvement}

Patients and or the public were not involved in setting the research question and were not involved in the design or conduct of the study.

\section{RESULTS}

\section{Respondent characteristics}

In total, $53.3 \%$ of respondents were nurses and $87.8 \%$ were female (table 1). Participants were from home visiting care stations (28.8\%), hospitals (25.7\%) and community health centres $(18.0 \%)$. About half of the interprofessional collaboration examples (CMC cases) reported by participants were male, with a mean age of 
Table 1 Demographic characteristics of participants and $\mathrm{CMC}$ for which participants experienced interprofessional collaboration

nor
Mean \pm SD $\quad \%$ or (range)

\section{Participants}

Gender ( $n=378)$

\begin{tabular}{|c|c|c|}
\hline Female & 332 & 87.8 \\
\hline Male & 46 & 12.2 \\
\hline Age $(n=368)$ & $45.7 \pm 9.1$ & $(24.0-68.0)$ \\
\hline \multicolumn{3}{|l|}{ Main qualification $(n=377)$} \\
\hline Physician & 48 & 12.7 \\
\hline Nurse & 201 & 53.3 \\
\hline Public health nurse & 62 & 16.4 \\
\hline Midwife & 5 & 1.3 \\
\hline Social worker & 8 & 2.1 \\
\hline Care worker & 2 & 0.5 \\
\hline Psychiatric social worker & 1 & 0.3 \\
\hline Physiotherapist & 5 & 1.3 \\
\hline Occupational therapist & 2 & 0.5 \\
\hline Nursery teacher & 16 & 4.2 \\
\hline School nurse & 13 & 3.4 \\
\hline Others & 14 & 3.7 \\
\hline $\begin{array}{l}\text { Years of work } \\
\text { experience }(n=377)\end{array}$ & $20.8 \pm 9.6$ & $(1.0-43.0)$ \\
\hline \multicolumn{3}{|l|}{ Affiliated institution $(n=378)$} \\
\hline $\begin{array}{l}\text { Hospital (paediatric } \\
\text { department) }\end{array}$ & 60 & 15.9 \\
\hline $\begin{array}{l}\text { Hospital (discharge } \\
\text { centre) }\end{array}$ & 37 & 9.8 \\
\hline Home visiting care station & 109 & 28.8 \\
\hline Community health centre & 68 & 18.0 \\
\hline Special school & 26 & 6.9 \\
\hline Child welfare institution & 55 & 14.6 \\
\hline Others & 23 & 6.1 \\
\hline $\begin{array}{l}\text { Years of experience in CMC } \\
\text { support }(n=362)\end{array}$ & $8.0 \pm 7.5$ & $(0.1-33.0)$ \\
\hline
\end{tabular}

\section{CMC}

Gender $(\mathrm{n}=374)$

\begin{tabular}{lll} 
Male & 190 & 50.8 \\
Female & 184 & 49.2 \\
$\begin{array}{l}\text { Age }(\mathrm{n}=366) \\
\text { Basic disease }(\mathrm{n}=371)\end{array}$ & $6.0 \pm 5.4$ & $(0.2-28.0)$ \\
$\begin{array}{l}\text { Chromosomal } \\
\text { abnormality/congenital } \\
\text { malformation }\end{array}$ & 121 & 32.6 \\
$\begin{array}{l}\text { Hypoxic encephalopathy/ } \\
\text { neonatal asphyxia }\end{array}$ & 111 & 29.9 \\
$\begin{array}{l}\text { Congenital metabolic } \\
\text { disease }\end{array}$ & 14 & 3.8 \\
\hline
\end{tabular}

Continued
Table 1 Continued

n or Mean \pm SD $\%$ or (range)

\begin{tabular}{|c|c|c|}
\hline Cardiac disease & 17 & 4.6 \\
\hline Kidney disease & 2 & 0.5 \\
\hline Respiratory disease & 17 & 4.6 \\
\hline Gastrointestinal disease & 7 & 1.9 \\
\hline $\begin{array}{l}\text { Nervous disease/muscle } \\
\text { disease }\end{array}$ & 37 & 10.0 \\
\hline $\begin{array}{l}\text { Blood disease/neoplastic } \\
\text { disease }\end{array}$ & 5 & 1.3 \\
\hline Others & 40 & 10.8 \\
\hline \multicolumn{3}{|c|}{ Medical care $(n=378)$ (Multiple answers) } \\
\hline $\begin{array}{l}\text { Suction from mouth and } \\
\text { nose }\end{array}$ & 246 & 65.1 \\
\hline $\begin{array}{l}\text { Suction from } \\
\text { tracheostomy tube }\end{array}$ & 224 & 59.3 \\
\hline Inhalation & 104 & 27.5 \\
\hline Ventilator therapy & 178 & 47.1 \\
\hline Oxygen therapy & 161 & 42.6 \\
\hline Tube feeding & 308 & 81.5 \\
\hline Parenteral nutrition & 14 & 3.7 \\
\hline Medical therapy & 195 & 51.6 \\
\hline Colostomy device & 11 & 2.9 \\
\hline Urethral catheterisation & 42 & 11.1 \\
\hline Pressure ulcer care & 50 & 13.2 \\
\hline Rehabilitation & 202 & 53.4 \\
\hline Others & 38 & 10.1 \\
\hline $\begin{array}{l}\text { Number of collaborated } \\
\text { professionals }(n=378)\end{array}$ & $7.1 \pm 3.4$ & $(1.0-20.0)$ \\
\hline
\end{tabular}

*Missing data were excluded from each analysis. $\mathrm{CMC}$, children with medical complexity.

$6.0 \pm 5.4$ years. The most common basic disease was chromosomal abnormality/congenital malformation (32.6\%), and $81.5 \%$ required tube feeding. The mean number of collaborating professionals per case was $7.1 \pm 3.4$.

\section{Distribution of each scale item}

Table 2 shows the item analysis results. Five items (9, $19,22,24$ and 30) met the exclusion criteria for item difficulty, and two items (28 and 30) met the exclusion criteria for population distribution. This resulted in six items being excluded, leaving 24 items for factor analysis.

\section{Factor analysis}

Factor analysis results are shown in table 3. The eigenvalues and scree plot suggested a two or three factor model. We repeated exploratory factor analysis with promax rotation until the factor loadings exceeded 0.40 , the difference in factor loadings between each factor became clear and the factors became theoretically 
Table 2 Item analyses for the interprofessional collaboration scale for children with medical complexity

\begin{tabular}{|c|c|c|c|c|c|c|c|c|c|c|}
\hline \multirow[b]{2}{*}{ Item } & & \multicolumn{5}{|l|}{ Importance } & \multicolumn{3}{|c|}{ Self-assessment } & \multirow[b]{2}{*}{ Exclusion } \\
\hline & & $\begin{array}{l}\text { Pass } \\
\text { efficiency* }\end{array}$ & $\begin{array}{l}\text { Item } \\
\text { difficulty† } \\
(\%)\end{array}$ & $\begin{array}{l}\text { Population } \\
\text { distribution¥ } \\
\text { (\%) }\end{array}$ & Kurtosis & Skewness & $\begin{array}{l}\text { Good-poor } \\
\text { analysis§ }\end{array}$ & $\begin{array}{l}\text { Item-total } \\
\text { correlationๆ } \\
\text { (r) }\end{array}$ & $P$ values & \\
\hline 2 & $\begin{array}{l}\text { I share information with other } \\
\text { professionals about how the } \\
\text { child and family perceive their } \\
\text { current living conditions. }\end{array}$ & $2.9 \pm 0.4$ & 1.2 & 100.0 & 1.9 & -2.0 & 0.000 & 0.810 & 0.000 & \\
\hline 3 & $\begin{array}{l}\text { I share information with other } \\
\text { professionals about how the } \\
\text { child and family wish to spend } \\
\text { their future life. }\end{array}$ & $2.9 \pm 0.4$ & 1.9 & 99.4 & 6.2 & -2.6 & 0.000 & 0.769 & 0.000 & \\
\hline 4 & $\begin{array}{l}\text { I share the content of } \\
\text { consultations with the child and } \\
\text { family with other professionals. }\end{array}$ & $2.7 \pm 0.5$ & 1.9 & 98.1 & 0.1 & -1.1 & 0.000 & 0.709 & 0.000 & \\
\hline 6 & $\begin{array}{l}\text { I share the expected changes in } \\
\text { the child and family with other } \\
\text { professionals. }\end{array}$ & $2.7 \pm 0.5$ & 1.9 & 99.4 & 0.7 & -1.2 & 0.000 & 0.760 & 0.000 & \\
\hline 7 & $\begin{array}{l}\text { I understand the perspective of } \\
\text { each professional involved with } \\
\text { the child and family. }\end{array}$ & $2.6 \pm 0.5$ & 4.9 & 98.0 & -0.1 & -1.0 & 0.000 & 0.727 & 0.000 & \\
\hline 8 & $\begin{array}{l}\text { I understand the abilities of each } \\
\text { professional involved with the } \\
\text { child and family. }\end{array}$ & $2.7 \pm 0.5$ & 1.9 & 99.4 & -0.3 & -1.1 & 0.000 & 0.707 & 0.000 & \\
\hline 9 & $\begin{array}{l}\text { I understand the position of } \\
\text { the institutions to which each } \\
\text { professional involved with the } \\
\text { child and family belongs. }\end{array}$ & $2.4 \pm 0.6$ & 6.2 & 92.9 & -0.6 & -0.6 & 0.000 & 0.689 & 0.000 & $x$ \\
\hline 13 & $\begin{array}{l}\text { I have explained the available } \\
\text { community resources and } \\
\text { details of services to the child } \\
\text { and family. }\end{array}$ & $2.8 \pm 0.5$ & 1.9 & 98.1 & 2.3 & -1.8 & 0.000 & 0.690 & 0.000 & \\
\hline 14 & $\begin{array}{l}\text { I have established support goals } \\
\text { for the child and family with } \\
\text { other professionals. }\end{array}$ & $2.7 \pm 0.5$ & 1.9 & 98.1 & 0.5 & -1.2 & 0.000 & 0.821 & 0.000 & \\
\hline 15 & $\begin{array}{l}\text { I am engaging in dialogue } \\
\text { with other professionals about } \\
\text { support objectives/planning for } \\
\text { the child and family. }\end{array}$ & $2.7 \pm 0.5$ & 1.2 & 99.4 & -0.3 & -1.1 & 0.000 & 0.803 & 0.000 & \\
\hline 16 & $\begin{array}{l}\text { I make efforts to agree with other } \\
\text { professionals about support } \\
\text { objectives/planning for the child } \\
\text { and family. }\end{array}$ & $2.6 \pm 0.6$ & 1.2 & 95.6 & 2.0 & -1.5 & 0.000 & 0.810 & 0.000 & \\
\hline 17 & $\begin{array}{l}\text { I clearly recognise the } \\
\text { responsibilities of each } \\
\text { professional on the team } \\
\text { involved with the child and } \\
\text { family. }\end{array}$ & $2.6 \pm 0.5$ & 1.2 & 98.1 & -0.3 & -0.9 & 0.000 & 0.824 & 0.000 & \\
\hline 18 & $\begin{array}{l}\text { I clearly recognise the presence } \\
\text { of a coordinator on the team } \\
\text { involved with the child and } \\
\text { family. }\end{array}$ & $2.6 \pm 0.6$ & 3.7 & 95.5 & 0.2 & -1.1 & 0.000 & 0.718 & 0.000 & \\
\hline
\end{tabular}

Continued 


\section{Table 2 Continued}

\begin{tabular}{|c|c|c|c|c|c|c|c|c|c|c|}
\hline \multirow[b]{2}{*}{ Item } & & \multicolumn{5}{|l|}{ Importance } & \multicolumn{3}{|c|}{ Self-assessment } & \multirow[b]{2}{*}{ Exclusion } \\
\hline & & $\begin{array}{l}\text { Pass } \\
\text { efficiency* }\end{array}$ & $\begin{array}{l}\text { Item } \\
\text { difficulty† } \\
(\%)\end{array}$ & $\begin{array}{l}\text { Population } \\
\text { distribution } ¥ \\
(\%)\end{array}$ & Kurtosis & Skewness & $\begin{array}{l}\text { Good-poor } \\
\text { analysis } \$\end{array}$ & $\begin{array}{l}\text { Item-total } \\
\text { correlationๆ } \\
\text { (r) }\end{array}$ & P values & \\
\hline 19 & $\begin{array}{l}\text { I clearly recognise the presence } \\
\text { of a leader on the team involved } \\
\text { with the child and family. }\end{array}$ & $2.4 \pm 0.7$ & 5.6 & 90.1 & 0.0 & -0.8 & 0.000 & 0.685 & 0.000 & $x$ \\
\hline 20 & $\begin{array}{l}\text { I understand specific details of } \\
\text { the services offered by each } \\
\text { professional involved with the } \\
\text { child and family. }\end{array}$ & $2.6 \pm 0.5$ & 1.9 & 99.4 & -1.1 & -0.7 & 0.000 & 0.793 & 0.000 & \\
\hline 21 & $\begin{array}{l}\text { I periodically review support } \\
\text { objectives/planning for the } \\
\text { child and family with other } \\
\text { professionals. }\end{array}$ & $2.6 \pm 0.6$ & 3.1 & 95.5 & 0.3 & -1.1 & 0.000 & 0.750 & 0.000 & \\
\hline 22 & $\begin{array}{l}\text { I do not hesitate to contact other } \\
\text { professionals regarding the child } \\
\text { and family. }\end{array}$ & $2.5 \pm 0.6$ & 6.8 & 92.0 & 0.6 & -1.1 & 0.000 & 0.689 & 0.000 & $x$ \\
\hline 23 & $\begin{array}{l}\text { I consult with other professionals } \\
\text { instead of leaving an issue } \\
\text { involving the child and family } \\
\text { unresolved. }\end{array}$ & $2.7 \pm 0.5$ & 1.2 & 98.1 & 0.3 & -1.2 & 0.000 & 0.707 & 0.000 & \\
\hline 24 & $\begin{array}{l}\text { I express my respect or provide } \\
\text { a positive assessment to other } \\
\text { professionals involved with the } \\
\text { child and family. }\end{array}$ & $2.5 \pm 0.7$ & 5.6 & 91.5 & -0.3 & -0.9 & 0.000 & 0.676 & 0.000 & $x$ \\
\hline 25 & $\begin{array}{l}\text { During normal periods, I operate } \\
\text { via a framework that permits } \\
\text { information sharing between the } \\
\text { professionals involved the child } \\
\text { and family. }\end{array}$ & $2.7 \pm 0.6$ & 1.2 & 96.2 & 0.7 & -1.3 & 0.000 & 0.787 & 0.000 & \\
\hline 26 & $\begin{array}{l}\text { During emergencies, I operate } \\
\text { via a framework that permits } \\
\text { immediate contact and response } \\
\text { between the professionals } \\
\text { involved with the child and } \\
\text { family. }\end{array}$ & $2.6 \pm 0.6$ & 0.6 & 95.1 & 2.2 & -1.6 & 0.000 & 0.672 & 0.000 & \\
\hline 27 & $\begin{array}{l}\text { I create opportunities to } \\
\text { meet face to face with other } \\
\text { professionals involved with the } \\
\text { child and family. }\end{array}$ & $2.5 \pm 0.6$ & 2.5 & 93.1 & 0.8 & -1.2 & 0.000 & 0.792 & 0.000 & \\
\hline 28 & $\begin{array}{l}\text { I have opportunities to } \\
\text { periodically meet with other } \\
\text { professionals involved with the } \\
\text { child and family. }\end{array}$ & $2.3 \pm 0.8$ & 1.2 & 84.4 & 0.1 & -0.9 & 0.000 & 0.700 & 0.000 & $x$ \\
\hline 29 & $\begin{array}{l}\text { I create opportunities to meet } \\
\text { with other professionals involved } \\
\text { with the child and family and } \\
\text { to discuss the challenges in } \\
\text { collaboration. }\end{array}$ & $2.4 \pm 0.7$ & 2.5 & 91.1 & 0.7 & -1.0 & 0.000 & 0.760 & 0.000 & \\
\hline 30 & $\begin{array}{l}\text { I work with the other } \\
\text { professionals involved with } \\
\text { the child and family while } \\
\text { incorporating new information. }\end{array}$ & $2.2 \pm 0.7$ & 7.4 & 85.4 & -0.1 & -0.6 & 0.000 & 0.667 & 0.000 & $x$ \\
\hline
\end{tabular}

Exclusion criteria for the item analyses.

The values which fit the exclusion criteria were written in bold.

${ }^{*}$ Average score: under 1.0 point.

†Percentage of 'don't know' and 'N/A': greater than $5 \%$ of the sample.

fPercentage of 'Important to a certain extent' and 'Important': lower than $90 \%$ of the sample.

$\S$ Difference of the average score between most high-scoring group and most low-scoring group: no significant difference ( $p \geq 0.05$ ).

ๆCorrelation coefficient between the item and the total score of all the items (but with exception of the item): less than 0.3 .

most explicable. Twelve items were removed, leaving 12 items on three factors for the final version of the ICC-CMC. Factor 1 ('sharing needs assessment skills') included four items central to interprofessional support covering: child's and family's values; consciousness and beliefs for the past, present and future, as presented by an understanding of the disease and symptoms; perceptions of current living conditions and future life wishes; and consultation content. Sharing this information with other professionals with different perspectives allows individuals to realise new aspects of the child and family's situation and to understand and assess the child 


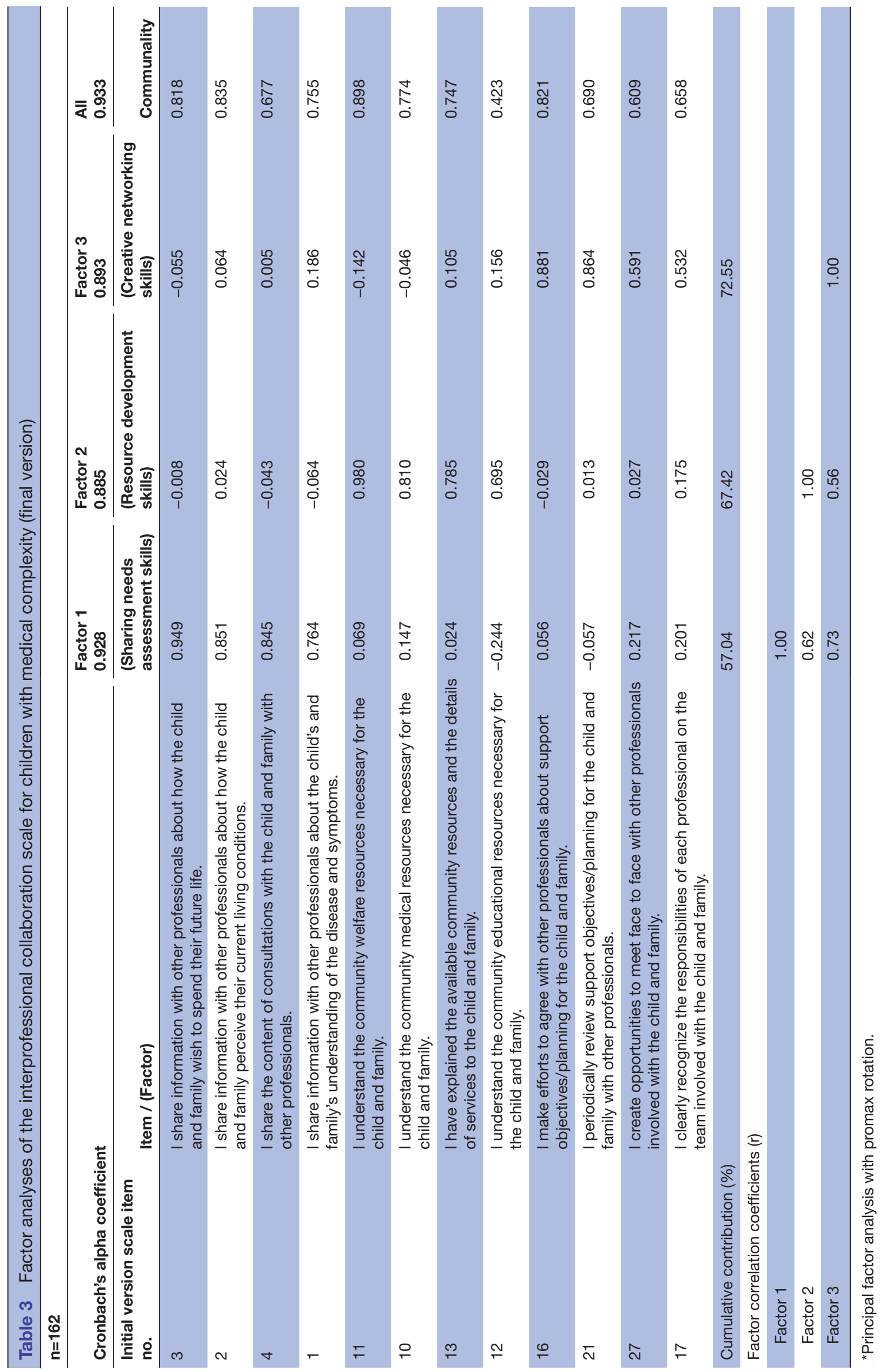

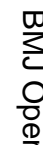

ज्ञ

등

$\frac{\bar{\sigma}}{\overrightarrow{0}}$

ตั

$\stackrel{\circ}{0}$

$\overrightarrow{\vec{\omega}}$

윽.

옴

옹

$\vec{G}$

온

N

气

$\stackrel{0}{\circ}$

뭉

产

$\stackrel{0}{\stackrel{0}{\otimes}}$

혹

吾

홍

긍.

官

$\frac{8}{3}$

음. 
and family more comprehensively. Factor 2 ('resource development skills') included four items that covered recognition of the importance of necessary or available community resources and services for medical care, welfare and education (eg, professional's skill, institution and system) and actively collecting information. This means that individuals appraise and explain the readily available resources, as well as those that need development for practical use. Factor 3 ('creative networking skills') included four items that represented how individuals: create opportunities to meet with other professionals to achieve the child's/family's goals; develop consensus with other professionals about support objectives/planning; clarify the role/ responsibility of each team member and periodically review support objectives/planning as a team member; and identify new objectives with other involved professionals. These processes cover the individual's contribution to sustainable and creative team practices.

The factor loadings were greater than 0.5 for each factor. The cumulative contribution of the three factors explained $72.55 \%$ of the variance. The correlation coefficients among the three factors were 0.56-0.73 (table 3).

\section{Internal consistency and validity of the final scale}

Cronbach's alpha coefficients were 0.93 for factor 1 , 0.89 for factor $2,0.89$ for factor 3 , and 0.93 for the total scale (table 3 ), showing the scale had sufficient internal consistency.

The three factors were entered as three latent factors in a confirmatory factor analysis model. The model fit showed GFI $=0.93$, AGFI $=0.88$, CFI $=0.97$ and RMSEA $=0.076$ and nearly satisfied the appropriate
Table 4 Construct validity of the interprofessional collaboration scale for children with medical complexity

\begin{tabular}{|c|c|c|}
\hline Factors & $\begin{array}{l}\text { Mean士SD } \\
\text { (Scores) }\end{array}$ & $\begin{array}{l}\text { Correlation with Fukui's } \\
\text { scale* }^{\star} \\
\text { (Pearson's correlation } \\
\text { coefficients) }\end{array}$ \\
\hline $\begin{array}{l}\text { Sharing needs } \\
\text { assessment skillst }\end{array}$ & $8.6 \pm 3.1$ & $0.63^{\star \star \star}$ \\
\hline $\begin{array}{l}\text { Resource } \\
\text { development skills† }\end{array}$ & $8.1 \pm 2.9$ & $0.60^{\star \star \star}$ \\
\hline $\begin{array}{l}\text { Creative networking } \\
\text { skills† }\end{array}$ & $6.9 \pm 3.5$ & $0.67^{\star \star \star}$ \\
\hline Total 12 items $\ddagger$ & $23.6 \pm 8.3$ & $0.72^{\star \star \star}$ \\
\hline
\end{tabular}

*Pearson's correlation coefficients between the total score of

Fukui's scale $(n=162) ;{ }^{* * *} p<0.001$.

†Total score range: $0-12$.

¥Total score range: 0-36 (sum of subscale scores).

criteria in all subjects; that is, construct validity was demonstrated (figure 1).

There were moderate correlations between the three ICC-CMC factors and Fukui's scale: 0.63 for factor 1, 0.60 for factor $2,0.67$ for factor 3 and 0.72 for the total scale $(\mathrm{p}<0.001)($ table 4$)$.

\section{DISCUSSION}

This study develops an original scale to assess interprofessional collaboration competency for CMC. We extracted 12 items on three factors that measured interprofessional collaboration competency for CMC (table 5). The

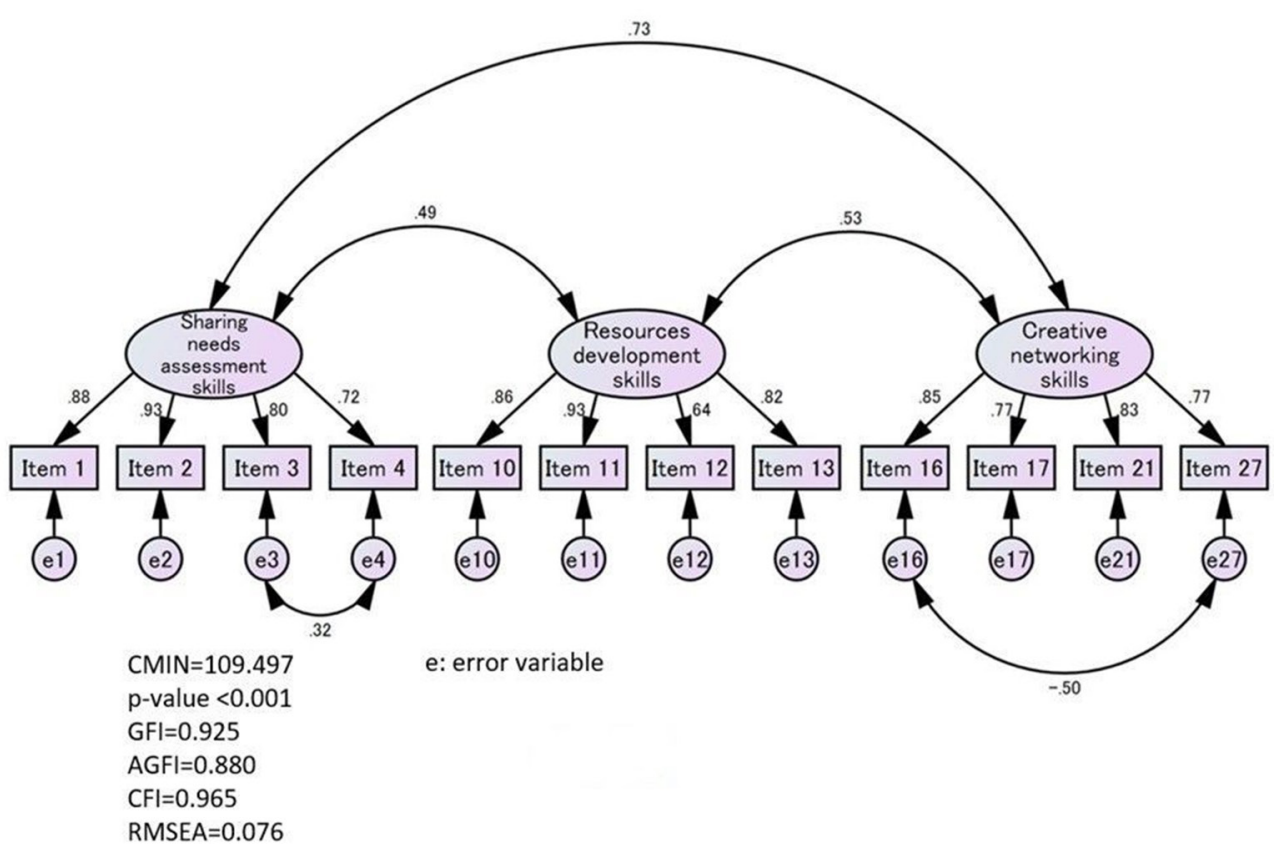

Figure 1 Confirmatory factor analysis for the interprofessional collaboration competency scale for children with medical complexity ( $n=216)$. AGFI, adjusted goodness of fit index; CFI, comparative fit index; CMIN, Chained Multilateral Index Number; GFI, goodness of fit index; RMSEA, root mean square error of approximation. 
Table 5 English and Japanese versions of the interprofessional collaboration competency scale for children with medical complexity

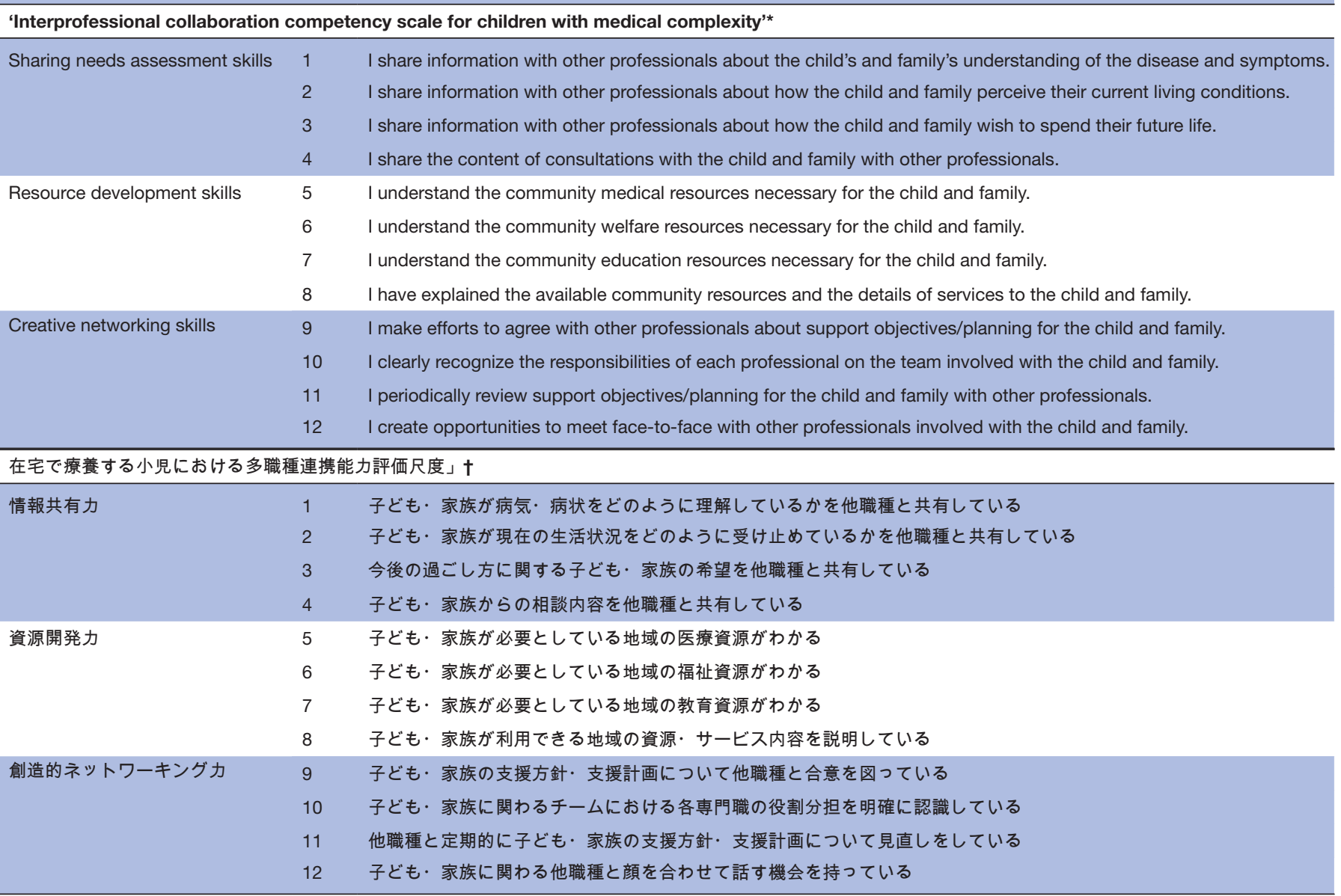

statistical evaluation of the scale was adequate, and the reliability and validity were demonstrated.

\section{Originality of the ICC-CMC}

Similar to previous interprofessional collaboration scales ${ }^{16-18}$ the ICC-CMC is based on professionals' self-reflection. However, the ICC-CMC has originality in that it measures interprofessional collaboration for CMC, a population with complex and chronic needs (eg, requiring community-based, longitudinal, comprehensive and creative competencies). Competencies can be developed by study or experience ${ }^{32}$ and grow with specialised work experience. ${ }^{15}$ Competency as evaluated by the ICC-CMC can also be developed by study or experience and increases with specialised work experience. This predicts positive outcomes for CMC in the future. ${ }^{15}$

\section{The structure of the ICC-CMC}

'Sharing needs assessment skills' (factor 1) refers to skills in understanding and assessing the child and family more comprehensively by sharing information with other professionals who offer different perspectives. A best practice statement in multiagency and interdisciplinary practice is that the child and family are central to the provision of valuable information from the expertise of other health professionals. ${ }^{33}$ Moreover, the Interprofessional
Education Collaborative Expert Panel ${ }^{35}$ arranges 'patient and family centred' treatment around four competencies that make it clear that children and their families are the central focus of interprofessional collaboration. CMC have intensive needs across different domains from hospital to the community and encompassing different sectors (eg, health, welfare and education) as their multiple health problems and needs interact. ${ }^{36}$ Interprofessional collaboration is necessary to determine and integrate the needs of CMC and their families, develop overarching goals and create comprehensive, proactive care plans. ${ }^{36}$

'Resource development skills' (factor 2) refers to the skills needed to appraise and develop the resources necessary for CMC and their families. Resources can be formal or informal and include medical homes for CMC, various individuals involved with care coordination and support groups. ${ }^{37}$ However, the resources and services available for CMC in Japan are limited. There are various multidisciplinary frameworks or complex care programmes for CMC in the USA that were developed by professionals in the field through trial and error and have demonstrated improved outcomes. ${ }^{38}$ Similarly, efforts are currently underway to expand resources for CMC in parts of Japan. The results of the present study suggest that it is desirable for interprofessionals to identify new resource needs of 
CMC and their families, as well as to understand obvious resources and put them into practical use. Kivimaki and Elovainio $^{27}$ extracted 'cooperation in developing and applying ideas' as an item to measure the climate for innovation in social and healthcare disciplines. For the innovative community, thinking of and developing new resource ideas is a necessary collaboration competency, rather than waiting for the structure of the support system to improve.

'Creative networking skills' (factor 3) refers to skills needed to create a sustainable and creative team in the community. A previous study of interprofessional collaboration competency identified similar factors: 'actions for accomplishing team goals' and 'attitudes and behaviors that improve team cohesion'. ${ }^{18}$ Creative networking skills may be facilitated through discussion with children, families and professionals, as well as use of tools such as the Goal Attainment Scale, care mapping ${ }^{34}$ or information communication technology. Moreover, creative actions that foster a sense of professionals and communities working together as a team will create a community-based network for other CMC and all children in the community.

Our confirmatory factor analysis suggested that the three concepts we identified were related to each other. These components are also part of the interprofessional collaboration process. The ICC-CMC clarifies the current reality of interprofessional collaboration competency and implies the mutual relationships among the concepts.

\section{Practical implications}

In future, the ICC-CMC may be useful for self-evaluation of interprofessional collaboration competency to improve individual practice or collaboration. Currently, there is no way for team members to assess each other's competency in interprofessional collaboration. However, use of the ICC-CMC as a tool to discuss mutual self-assessment may benefit teams in developing specific collaboration improvement strategies. Moreover, if the scale is used in the wider community, it may also assess the actual conditions of interprofessional collaboration beyond institutions and inform a strategy for discussing and promoting community-wide collaboration. These benefits will enhance the well-being of CMC, their families and the wider community and contribute to community building for all children.

\section{Limitations}

The present study has several limitations. First, the response rate was slightly lower at about $18 \%$ compared with the $20 \%-30 \%$ that is generally found with mailed questionnaires for experts for CMC. As low response rates can introduce bias into survey results, it is necessary to test for non-response effects to maximise validity for further study. Second, as the study design was cross-sectional, it could not be revealed an association between ICC-CMC and collaboration practices or outcomes for CMC and their families. Therefore, a longitudinal design is needed to determine the predictive validity of the ICC-CMC. Lastly, the ICC-CMC is developed for self-evaluation on their ability. Self- evaluations are more detailed, accessible and easy to administer and interpret in general. However, they are limited by the fact that individuals are likely to reveal their positive side only. Therefore, there is value in combining the other methods to ensure optimum understanding of the expert's competency in the future.

\section{CONCLUSION}

The ICC-CMC has 12 items on three domains: 'sharing needs assessment skills', 'resource development skills' and 'creative networking skills.' The scale has acceptable internal consistency and concurrent validity. The ICC-CMC has potential to advance both individual practices and team performance in interprofessional collaboration, in addition to improving satisfaction and outcomes for $\mathrm{CMC}$ and their families.

Acknowledgements The authors would like to thank all participants in our survey and interviews who willingly shared their time. The authors also express appreciation to Associate Professor A Okochi, A Arimoto, Assistant Professor K Shiratani, E Ito and all members of the Department of the Community Health Nursing, Graduate School of Medicine, Yokohama City University, for providing valuable advice throughout the study process.

Contributors KS and ET contributed to develop the concept and design of this study. ET was responsible for acquiring the Institutional Review Board (IRB) approval of this study. KS was responsible for data collection and analysis. KS were responsible for drafting and revising the manuscript. ET is responsible for study supervision and reporting of study results. All authors have read and approved the final manuscript.

Funding This work was supported by the Pfizer Health Research Foundation (16-9-015).

Disclaimer The funder had no role in the data collection and analysis, decision to publish, or preparation of the manuscript.

Competing interests Non-financial associations that may be relevant to the submitted manuscript.

Patient consent Not required.

Ethics approval The Institutional Review Board of the Medical Department of Yokohama City University approved this study on 28 July 2016 (no. A160728122). All participants provided written informed consent. The questionnaire contained no identifying details to ensure participant anonymity.

Provenance and peer review Not commissioned; externally peer reviewed.

Data sharing statement No additional data available.

Open access This is an open access article distributed in accordance with the Creative Commons Attribution Non Commercial (CC BY-NC 4.0) license, which permits others to distribute, remix, adapt, build upon this work non-commercially, and license their derivative works on different terms, provided the original work is properly cited and the use is non-commercial. See: http://creativecommons.org/ licenses/by-nc/4.0/

(c) Article author(s) (or their employer(s) unless otherwise stated in the text of the article) 2018. All rights reserved. No commercial use is permitted unless otherwise expressly granted.

\section{REFERENCES}

1. McPherson M, Arango P, Fox $\mathrm{H}$, et al. A new definition of children with special health care needs. Pediatrics 1998;102:137-9.

2. Cohen E, Kuo DZ, Agrawal R, et al. Children with medical complexity: an emerging population for clinical and research initiatives. Pediatrics 2011;127:529-38. 
3. Cohen E, Berry JG, Camacho X, et al. Patterns and costs of health care use of children with medical complexity. Pediatrics 2012;130:e1463-70.

4. Health, Labour and Welfare Statistics Association. Journal of health and welfare statistics 2014/2015. Tokyo: Health, Labour and Welfare Statistics Association, 2015:62-3. (in Japanese).

5. Ministry of Health, Labour and Welfare. Equal Employment, Children and Families Bureau, Japan. http://www.mhlw.go.jp/file/05-Shingikai12601000-Seisakutoukatsukan-Sanjikanshitsu_Shakaihoshoutantou/ 0000028538.pdf (accessed 27 Dec 2016).

6. Ministry of Health, Labour and Welfare. Social Welfare and War Victims' Relief Bureau, Japan. www.mhlw.go.jp/toukei/list/dl/ seikatsu_chousa_c_h23.pdf (accessed 13 Jul 2016).

7. Srivastava R, Stone BL, Murphy NA. Hospitalist care of the medically complex child. Pediatr Clin North Am 2005;52:1165-87.

8. Ethics committee of Japan Pediatric Society. Current trends and problems about medical care for children with very severe motor and intellectual disabilities. The Journal of the Japan Pediatric Society 2008;112:94-101. (in Japanese).

9. Wang KW, Barnard A. Technology-dependent children and their families: a review. J Adv Nurs 2004;45:36-46.

10. Ministry of Health, Labour and Welfare. Core human resource development workshop, Japan. http://www.mhlw.go.jp/stf/ seisakunitsuite/bunya/0000061944.html (accessed 26 Jan 2017).

11. Boudreau AA, Perrin JM, Goodman E, Kurowski D, et al. Care coordination and unmet specialty care among children with special health care needs. Pediatrics 2014;133:1046-53.

12. Mosquera RA, Avritscher EB, Samuels CL, et al. Effect of an enhanced medical home on serious illness and cost of care among high-risk children with chronic illness: a randomized clinical trial. JAMA 2014;312:2640-8.

13. Cohen E, Lacombe-Duncan A, Spalding K, et al. Integrated complex care coordination for children with medical complexity: a mixedmethods evaluation of tertiary care-community collaboration. BMC Health Serv Res 2012;12:366.

14. Phipps DL, Morris RL, Blakeman T, et al. What is involved in medicines management across care boundaries? A qualitative study of healthcare practitioners' experiences in the case of acute kidney injury. BMJ Open 2017;7:e011765.

15. Spencer L, Spencer S. Competence at work: model for superior performance. New York: John Wiley \& Sons, Inc, 1993.

16. Kenaszchuk C, Reeves S, Nicholas D, et al. Validity and reliability of a multiple-group measurement scale for interprofessional collaboration. BMC Health Serv Res 2010;10:83.

17. Heinemann GD, Schmitt MH, Farrell MP, et al. Development of an attitudes toward health care teams scale. Eval Health Prof 1999;22:123-42.

18. Sakai I, Yamamoto T, Takahashi Y, et al. Development of a new measurement scale for interprofessional collaborative competency: the Chiba Interprofessional Competency Scale (CICS29). $J$ Interprof Care 2017;31.

19. D'Amour D, Ferrada-Videla M, San Martin Rodriguez L, et al. The conceptual basis for interprofessional collaboration: core concepts and theoretical frameworks. J Interprof Care 2005;19:116-31.

20. Henneman EA, Lee JL, Cohen JI. Collaboration: a concept analysis. $J$ Adv Nurs 1995;21:103-9.
21. World Health Organization. Human Resources for Health, Health Professions Networks Nursing \& Midwifery. Framework for Action on Interprofessional Education \& Collaborative Practice. Geneva: World Health Organization, 2010.

22. Anderson NR, West MA. Measuring climate for work group innovation: development and validation of the team climate inventory. J Organ Behav 1998;19:235-58.

23. Gregson BA, Cartlidge AM, Bond J. Development of a measure of professional collaboration in primary health care. $J$ Epidemiol Community Health 1992;46:48-53.

24. D'Amour D, Goulet L, Labadie J-F, et al. A model and typology of collaboration between professionals in healthcare organizations. BMC Health Serv Res 2008;8.

25. Fujita J, Fukui S, Ikezaki S. Development of interprofessional collaboration performance scale for medical and care staff in home care. Journal of Health and Welfare Statistics 2015;62:1-9. (in Japanese).

26. Fukui S. A measure to quantify the face-to-face cooperation level among home health care providers. The Japanese Academy of Home Care Physicians 2014;16-. (in Japanese).

27. Kivimaki M, Elovainio M. A short version of the team climate inventory: development and psychometric properties. J Occup Organ Psychol 1999;72:241-6.

28. Leutz WN. Five laws for integrating medical and social services: lessons from the United States and the United Kingdom. Milbank Q 1999;77:77-110.

29. Uijen AA, Schellevis FG, van den Bosch WJHM, et al. Nijmegen continuity questionnaire: development and testing of a questionnaire that measures continuity of care. J Clin Epidemiol 2011;64:1391-9.

30. Cortina JM. What is coefficient alpha? An examination of theory and applications. J App/ Psychol 1993;78:98-104.

31. Browne MW, Cudeck R. Alternative ways of assessing model fit. Newbury: CA: Sage, 1993:136-62.

32. ten Cate O. Entrustability of professional activities and competencybased training. Med Educ 2005;39:1176-7.

33. Carter B, Cummings J, Cooper L. An exploration of best practice in multi-agency working and the experiences of families of children with complex health needs. What works well and what needs to be done to improve practice for the future? J Clin Nurs 2007;16:527-39.

34. Dewan T, Cohen E. Children with medical complexity in Canada. Paediatr Child Health 2013;18:518-22.

35. Interprofessional Education Collaborative Expert Panel. Core competencies for interprofessional collaboration practice: Report of an expert panel. Washington, DC: Interprofesional Education Collaborative, 2011.

36. Berry J, Agrawal R, Cohen E, et al. The landscape of medical care for children with medical complexity. Overland Park: Children's Hospital Association, 2013.

37. Glader L, Plews-Ogan J, Agrawal R. Children with medical complexity: creating a framework for care based on the International Classification of Functioning, Disability and Health. Dev Med Child Neurol 2016;58:1116-23.

38. Antonelli R, McAllister J, Popp J. Making care coordination a critical component of the pediatric health system: a multidisciplinary framework. New York: Commonwealth Fund pub, 2009. 